Original Article

\title{
Demographic and Clinicopthologic Properties of Patients Operated for Adrenal Masses
}

\author{
Ali Aktekin ${ }^{1 *}$, Umut Kına², Seher Tanrıkulu³, Gulistan Gumrukcu ${ }^{4}$ and Meryem Gunay Gurleyik ${ }^{2}$ \\ ${ }^{1}$ Division of General Surgery, Giresun Medical Faculty, Giresun University, Giresun, Turkey \\ ${ }^{2}$ Division of General Surgery, Saglık Bilimleri University, Haydarpasa Numune Education and Research Hospital, Istanbul, \\ Turkey \\ ${ }^{3}$ Division of Endocrinology and Metabolism, Saglık Bilimleri University, Haydarpasa Numune Education and Research \\ Hospital, Istanbul, Turkey \\ ${ }^{4}$ Division of Pathology, Saglık Bilimleri University, Haydarpasa Numune Education and Research Hospital, Istanbul, \\ Turkey
}

\begin{abstract}
Background: The prevalence of adrenal incidentaloma is nearly 4 to $10 \%$ and increases with age. Most adrenal masses are nonfunctioning adrenocortical adenomas and found as an adrenal incidentaloma in $80 \%$ of cases, but also be conditions requiring therapeutic intervention. We presented our patients with adrenal masses and their management.

Patients and methods: We documented age and gender of patients, and also size, clinical and histopathologic diagnoses of the adrenal masses; diagnostic dilemmas and preferred operation techniques in case series between 01 January; 2015 and 31 December; 2019.

Results: We performed 59 operations on 41 women and 18 men patients with median age of 52.67 years; 25 open and 34 laparoscopic adrenalectomies. Histopathologic analysis revealed 28 adrenocortical adenoma, 5 pheochromocytoma, 7 myelolipoma and one pseudocyst, endothelial cyst and adrenal medullar hemorrhage. Malign ones are 5 adrenocortical carcinoma, 5 metastases from non-squamous lung cancer, 2 from renal cell carcinomas and one from colon adenocarcinoma metastases, and one follicular dendritic cell sarcoma and one lymphoma. Two of non-squamous lung cancer metastases were rarely seen poorly differentiated carcinoma showing enteric differentiation and pleomorphic carcinoma. In addition, one renal cell carcinoma was metastases to contralateral adrenal. One of adrenal mass was operated with a miss diagnosis of adrenocortical carcinoma but reported as a follicular dentritic cell sarcoma after histopathologic analysis.

Discussion: Atypical sarcomas, unexpected tumor metastases and also skip to other adrenal site metastases can be found as an adrenal mass. Adrenalectomy should be performed if hormonal activity or malignancy present. Laparoscopic surgery is feasible in benign lesions and also in some malignant lesions.
\end{abstract}

Keywords

Adrenal mass, Adrenal incidentaloma, Adrenal cancer, Adrenalectomy

\section{Introduction}

The incidence of adrenal masses (AM) increases with widely use of diagnostic radiologic devices and most of time we found them as an adrenal incidentaloma (AI). Al is an asymptomatic AM detected on imaging studies performed for another medical situation. With progress on imaging technology, the prevalence of Al has become up to 4 to $10 \%$ and increases with age [1]. The prevalence of Al increases approximately $5 \%$ on abdominal computed tomography reports, and even as high as $32 \%$ on post-mortem examinations [2].

Als are nonfunctioning adrenocortical adenomas in $80 \%$ cases, but may also represent conditions requiring therapeu- tic intervention; for instance, hormone producing masses and/or adrenocortical carcinoma (ACC). Their incidences are

*Corresponding author: Ali Aktekin, Division of General Surgery, Giresun Medical Faculty, Giresun University, Gazipaşa Yerleşkesi Debboy Mevkii-Merkez/GiRESUN Zip Code: 28100 Turkey, Tel: +90-(532)-5987207, Fax: +90-(454)-310-16-99

Accepted: September 01, 2020

Published online: September 03, 2020

Citation: Aktekin A, Kına U, Tanrıkulu S, et al. (2020) Demographic and Clinicopthologic Properties of Patients Operated for Adrenal Masses. J Surgical Endocrinol 2(1):30-35 
Citation: Aktekin A, Kına U, Tanrıkulu S, et al. (2020) Demographic and Clinicopthologic Properties of Patients Operated for Adrenal Masses. J Surgical Endocrinol 2(1):30-35

reported up to $23.0 \%$ and $12.0 \%$, respectively. Cysts, ganglioneuroma, myelolipoma, hematoma and metastases from lung, breast and renal cancer, malign melanoma, and lymphoma could also present as an AM [3].

The guidelines of the European Society of Endocrinology collaborated with the European Network for the Study of Adrenal Tumors, the American Association of Clinical Endocrinologists collaborated with the American Association of Endocrine Surgeons and Korean Endocrine Society and some reviews discussed and reported the management of AMs $[2,4,5]$. We presented our patients operated for AMs and their clinical and histopathologic remarkable points and preferred surgical techniques.

\section{Patients and Methods}

\section{Clinical evaluation}

We assessed any AM clinically for adrenal hormone over activity. We performed other diagnostic work-ups if lesion is more than one $\mathrm{cm}$ or lesions that are less than $1 \mathrm{~cm}$ but, clinical signs and symptoms are suggestive of adrenal hormone excess. We preferred adrenalectomy (ADX) for unilateral AMs if significant hormone excess present. Hormonal evaluation for cortisol excess; 8.00 a.m. cortisol, DHEA-S, ACTH and in hypertensive patients for evaluation of hyperaldosteronism; plasma renin activity, and serum aldosterone were evaluated. Urinary normetanephrine, and metanephrine were measured. Overnight one $\mathrm{mg}$ dexamethasone suppression test was performed in all of the cases. We performed hormonal evaluation 6 months after the initial visit and annually in subsequent visits for non hormone secreting AMs.

We used non-contrast $\mathrm{CT}$ in first line radiological diag- nostic modality and diagnosed the $A M$ as a benign lesion if measured Hounsfield units is low or equal the 10, homogeneous character and smaller than $4 \mathrm{~cm}$. We did not use any further imaging modalities in these circumstances. On the other hand, if the AM is indeterminate and do not have significant hormone excess, we used other imaging modalities or interval imagings like non-contrast CT or MRI in 6-12 months. We performed ADX if lesion increased in size by more than $20 \%$ or $5 \mathrm{~mm}$ in maximum diameter. If any lesions consisted of heterogeneity and invasive components with suspicious of malignancy, we used other diagnostic modalities, especially MRI to plan the extent of operation.

\section{Management of the adrenal masses}

We generally performed laparoscopic ADX for unilateral AM if less than $6 \mathrm{~cm}$ in diameter and without any evidences of local invasion was present, but preferred open ADX if lesions were more than $6 \mathrm{~cm}$ in diameter and/or any evidences of local invasion present obeying the advices of guidelines and some reviews $[2,4,5]$. In time, with the increase in the skill of surgery, we also operated some malignant masses or lesions larger than $6 \mathrm{~cm}$ as we performed all operations trans-abdominally.

\section{Patients}

We documented age, gender and also size and clinical and histopathologic diagnoses of the AMs; diagnostic dilemmas and preferred operation techniques in case series between 01 January; 2015 and 31 December; 2019 at Haydarpasa Numune Education and Research Hospital. We especially documented and highlighted the differences in the diagnoses of the masses before surgery as a clinical diagnosis and after

Table 1: Clinical and histopahologic analyses and demographic properties of patients operated due to adrenal masses.

\begin{tabular}{|c|c|c|c|c|c|c|}
\hline & & \multirow[b]{2}{*}{ Total Patients } & \multicolumn{2}{|c|}{ Clinical Diagnosis } & \multicolumn{2}{|c|}{ Histopthalogic Diagnosis } \\
\hline & & & $\begin{array}{l}\text { Benign } \\
\text { Suspected }\end{array}$ & $\begin{array}{l}\text { Malign } \\
\text { Suspected }\end{array}$ & $\begin{array}{l}\text { Benign } \\
\text { Reported }\end{array}$ & $\begin{array}{l}\text { Malign } \\
\text { Reported }\end{array}$ \\
\hline \multicolumn{2}{|l|}{ Total Patients } & 59 & 41 & 18 & 44 & 15 \\
\hline \multicolumn{2}{|c|}{ Median Age Of Patients (Min-Max) Years } & $52.67(17-82)$ & $50.36(17-74)$ & $58.23(40-82)$ & $51(17-74)$ & $50.07(35-82)$ \\
\hline \multirow[t]{2}{*}{40 years } & $<$ & $8(13.5 \%)$ & 8 & 0 & 7 & 1 \\
\hline & $\geq$ & $51(85.5 \%)$ & 33 & 18 & 37 & 14 \\
\hline \multirow[t]{2}{*}{ Gender } & Man & $18(30.5 \%)$ & 8 & 10 & 8 & 10 \\
\hline & Woman & $41(69.4 \%)$ & 33 & 8 & 36 & 5 \\
\hline \multirow[t]{2}{*}{ Site of the Mass } & Right & $27(45.7 \%)$ & 18 & 9 & 21 & 6 \\
\hline & Left & $32(54.3 \%)$ & 23 & 9 & 23 & 9 \\
\hline \multicolumn{2}{|c|}{ Radiologic Size (mm) } & $51.89(14-200)$ & $44.5(14-200)$ & $69.29(15-140)$ & $46.2(16-200)$ & $69.21(14-140)$ \\
\hline \multirow[t]{2}{*}{$40 \mathrm{~mm}$} & $<$ & $24(40.6 \%)$ & 22 & 2 & 21 & 3 \\
\hline & $\geq$ & $35(58.3 \%)$ & 20 & 15 & 23 & 12 \\
\hline \multirow[t]{2}{*}{$60 \mathrm{~mm}$} & $\leq$ & $42(71.18)$ & 35 & 7 & 35 & 7 \\
\hline & $>$ & $17(28.58 \%)$ & 7 & 10 & 9 & 8 \\
\hline \multicolumn{2}{|c|}{ Size after Histopathologic Analysis (mm) } & $62.27(10-190)$ & $52.17(10-160)$ & $86.64(14-190)$ & $52.5(10-160)$ & $93(14-190)$ \\
\hline \multirow{2}{*}{$\begin{array}{l}\text { Surgical } \\
\text { Technique }\end{array}$} & Open & $25(42.3 \%)$ & 10 & 15 & 11 & 14 \\
\hline & Laparoscopic & 34 (57.6\%) & 31 & 3 & 33 & 1 \\
\hline
\end{tabular}


Citation: Aktekin A, Kına U, Tanrıkulu S, et al. (2020) Demographic and Clinicopthologic Properties of Patients Operated for Adrenal Masses. J Surgical Endocrinol 2(1):30-35

surgery as a histopathologic diagnosis. The ethical approval number is 771/12/2019-18 and taken from SBU Haydarpasa Numune Education and Research Hospital.

\section{Results}

\section{Results of clinical and histopathologic evalua- tions}

We performed 59 operations on 41 (69\%) women and 18 (21\%) men patients and $86 \%$ were older than 40 years with median age of 52.67 years. Thirty two (nearly $54 \%$ ) of AMs was located on the left site. Radiological median size of the AMs is $51.89 \mathrm{~mm}$ but histopathologic analysis revealed the median size of the tumors was $62.27 \mathrm{~mm}$. Malign lesions were nearly $20 \mathrm{~mm}$ bigger than benign ones. Radiological $40.67 \%$ (24 out 59 patients) of AMs are smaller than $40 \mathrm{~mm}$ and $71.18 \%$ (42 out 59 patients) smaller than $60 \mathrm{~mm}$. We performed 25 (42.37\%) open and 34 (57.67\%) laparoscopic ADX (Table 1).

Preoperatively, 19 (32.27\%) patients out of 59 diagnosed were non-functional AMs, and others were 9 Cushing' syndromes, 4 Conn syndromes, 6 pheochromocytomas, 3 myelolipomas, 8 ACCs, 6 metastases from lung, 2 from renal cancer, one from colon and one metastasis from breast cancer. According to clinical evaluations, preoperatively we diagnosed 42 benign and 17 malign lesions, but histopthalogic analysis revealed only 44 benign and 15 malign lesions. We found 37 out of 45 benign lesions were women but 11 of 15 malign lesions were men. Histopathologic analysis revealed 28 $(47.45 \%)$ of all 59 patients were adrenocortical adenomas, 5 pheochromocytomas, myelolipomas and one pseudocyst, endothelial cyst, ganlioneuroma, and adrenal medullar hemorrhage. Three out of 12 patients diagnosed as benign lesions before operation revealed malign, and 4 out of 8 malign suspected lesions revealed benign lesions after histopthalogic analysis (Table 2). Malign ones were 5 ACCs, 5 metastases from non-squamos lung cancer, 2 renal cell carcinoma, one colon metastases, one dendritic cell sarcoma, and one lymphoma (Table 2 and Table 3). In addition, three out of five our ACCs were hormone active.

Although age of ACC patients are nearly 15 years younger than lung cancer metastases (46.6 to 60.2 years) but much more larger in size (98.8 to $57.6 \mathrm{~mm}$ ). Renal cell and colon cancer metastases were larger than both ACC and lung cancer metastases but lymphoma $(180 \mathrm{~mm})$ and dendritic cell sarcoma $(190 \mathrm{~mm})$ are much large than all of them. We interestingly found that although three lung cancer metastases were adenocancer metastases, the other two were very rarely seen lung cancers; one was metastasis of poorly differentiated lung carcinoma showing enteric differentiation and other one was pleomorphic lung carcinoma. In addition, one renal cell carcinoma was metastases to contralateral adrenal site. Both lymphoma and very rarely seen dendritic cell carcinoma of adrenal tumors were adjudged to operation with miss diagnosis of AAC (Table 3).

\section{Management of the adrenal masses}

We performed laparoscopic operation in 20 out of 24 lesions smaller than $40 \mathrm{~mm}$ and 33 out of 42 patients with tumors less than $60 \mathrm{~mm}$, but we performed laparoscopic operation on 14 lesions bigger than $40 \mathrm{~mm}$ and only one patient whose lesion was bigger than $60 \mathrm{~mm}$ (Table 4).

\section{Discussion}

Prevalence of AMs tends to increase with age and up to

Table 2: Comparisons of the clinical and histopathologic diagnoses of patients operated due to adrenal masses.

\begin{tabular}{|l|l|l|}
\hline & Clinical Diagnosis & $\begin{array}{l}\text { Histopthalogic Diagnosis } \\
\text { Adrenocortical Adenoma }\end{array}$ \\
\hline Non-Functional Adenoma & 19 & 28 \\
\hline Cushing's Syndrome & 9 & \\
\hline Conn Syndrome & 4 & 5 \\
\hline Pheochromacytoma & 6 & 7 \\
\hline Myelolipoma & 3 & 1 \\
\hline Ganglioneuroma & 0 & 1 \\
\hline Pseudocyst & 0 & 1 \\
\hline Endotheliaal Cyst & 0 & 1 \\
\hline Adrenal Medullary Hemorrhage & 0 & 5 \\
\hline Adenocortical Carcinoma & 8 & 5 \\
\hline Metastases From Lung Cancer & 6 & 2 \\
\hline Metastases From Renal Cell Carcinoma & 2 & 0 \\
\hline Metastasis From Breast Cancer & 1 & 1 \\
\hline Metastasis From Colon Cancer & 1 & 1 \\
\hline Dendtritic Cell Sarcoma & 0 & 1 \\
\hline Lymphoma & 0 & 59 \\
\hline Total Patients & 59 & \\
\hline & & \\
\hline & & \\
\hline
\end{tabular}


Citation: Aktekin A, Kına U, Tanrıkulu S, et al. (2020) Demographic and Clinicopthologic Properties of Patients Operated for Adrenal Masses. J Surgical Endocrinol 2(1):30-35

Table 3: Remarkable properties of histopathologically malign lesions.

\begin{tabular}{|c|c|c|c|c|c|c|}
\hline & \multirow{2}{*}{$\begin{array}{l}\text { Total } \\
\text { Patients }\end{array}$} & \multicolumn{2}{|c|}{ Gender } & \multirow{2}{*}{$\begin{array}{l}\text { Age Median } \\
\text { year } \\
\text { (min-max) }\end{array}$} & \multirow{2}{*}{$\begin{array}{l}\text { Size After } \\
\text { Histopathologic } \\
\text { Analysis } \\
\text { mm } \\
\text { (min-max) }\end{array}$} & \multirow[t]{2}{*}{ Remarkable points } \\
\hline & & Man & Woman & & & \\
\hline ACC & 5 & 4 & 1 & $46.6(35-57)$ & $98.8(14-190)$ & - Three of them hormone active \\
\hline $\begin{array}{l}\text { Metastasis from } \\
\text { Lung Cancer }\end{array}$ & 5 & 5 & 0 & $60.2(48-65)$ & $57.6(14-95)$ & $\begin{array}{l}\text { - One Patient: Metastasis of non- } \\
\text { small cell - enteric differentiation } \\
\text { showing poorly differentiated } \\
\text { lung cancer. } \\
\text { - One Patient: Metastasis of } \\
\text { pleomorphic carcinoma of lung. }\end{array}$ \\
\hline $\begin{array}{l}\text { Metastasis from } \\
\text { Renal Cell } \\
\text { Carcinoma }\end{array}$ & 2 & 1 & 1 & $77(72-82)$ & $80(40-120)$ & $\begin{array}{l}\text { - One patient have metastasis to } \\
\text { contralateral adrenal site }\end{array}$ \\
\hline $\begin{array}{l}\text { Metastasis From } \\
\text { Colon Cancer }\end{array}$ & 1 & 0 & 1 & 75 & 70 & \\
\hline Lymphoma & 1 & 0 & 1 & 53 & 190 & - Clinically misdiagnosed as an ACC \\
\hline $\begin{array}{l}\text { Dendritic Cell } \\
\text { Sarcoma }\end{array}$ & 1 & 0 & 1 & 58 & 170 & - Clinically misdiagnosed as an ACC \\
\hline
\end{tabular}

Table 4: Comparisons of patients operated open or laparoscopic techniques for adrenal masses.

\begin{tabular}{|c|c|c|c|}
\hline & & \multicolumn{2}{|c|}{ Surgery Technique } \\
\hline & & Open & Laparoscopic \\
\hline \multicolumn{2}{|l|}{ Total Patients } & 25 & 34 \\
\hline \multirow[t]{2}{*}{ Site of the Mass } & Right & 10 & 17 \\
\hline & Left & 15 & 17 \\
\hline \multicolumn{2}{|l|}{ Radiologic Size (mm) } & $72.9(14-200)$ & $36.6(16-85)$ \\
\hline \multirow[t]{2}{*}{$40 \mathrm{~mm}$} & $<$ & 4 & 20 \\
\hline & $\geq$ & 21 & 14 \\
\hline \multirow[t]{2}{*}{$60 \mathrm{~mm}$} & $\leq$ & 9 & 33 \\
\hline & $>$ & 16 & 1 \\
\hline \multirow[t]{2}{*}{ Clinical Diagnosis } & Benign Suspected & 11 & 31 \\
\hline & Malign Suspected & 14 & 3 \\
\hline \multirow[t]{2}{*}{ Histopthalogic Diagnosis } & Benign Reported & 9 & 33 \\
\hline & Malign Reported & 16 & 1 \\
\hline \multicolumn{2}{|c|}{ Size after Histopathologic Analysis ( $\mathrm{mm}$ ) } & $88.33(14-190)$ & $43.8(10-90)$ \\
\hline
\end{tabular}

$10 \%$ in the 8 th decade $[6,7]$. In our research, median age is 52 and the youngest patient is at 17 and oldest one is 82 -yearsold. Although some researchers reported no differences between genders, others reported that women more often develop an $\mathrm{AM}$, even three times more common in women than men patients [6]. Similarly, according to our data, AMs were two times more prevalent in women patients.

Most patients with AMs present hormone inactive, high lipid content and less than $4 \mathrm{~cm}$ in size. Most of AMs do not require surgical resection. On the other hand, nearly one fifth of AMs is hormone active and/or has malignancy risks. In previous analyses, the percentage of hormone inactive tumors was reported 70 to $94 \%$, but we found $63.7 \%$ of AMs in our patients $[6,8]$. In addition, the clinically silent pheochromacytomas must be in mind in the surgical decision. The prevalence of pheochromocytoma in clinical and surgical studies reported 7 to $10 \%$ [5]. Although, subclinical Cushing' s syndrome and Conn syndrome are mostly reported hormonal conditions, we found Cushing' s syndrome and pheochromocytoma mostly in our patients [9].

The prognosis of ACC is generally poor, and the overall 5 -year survival rate after diagnosis is $7 \%$ to $65 \%$ [10]. Given these facts, it is important to promptly determine whether or not a tumor discovered as an AM is an ACC. The incidence of ACCs in the general population is only $1-/ 1,000,000 /$ year and ACCs constitutes $1.4 \%$ of the AMS [11]. In a cohort study, 
Citation: Aktekin A, Kına U, Tanrıkulu S, et al. (2020) Demographic and Clinicopthologic Properties of Patients Operated for Adrenal Masses. J Surgical Endocrinol 2(1):30-35

ACC was diagnosed in $8.4 \%$ of subjects referred for ADX [12]. In some series, the mean malignancy rate was reported between $3.5 \%$ and $34 \%$ due to varying selection criteria but it was $8.4 \%$ of our patients [13].

Determination of the malignant potential of an AM is more difficult. The size criteria for malignancy are not definitive and are derived from some selected series. The actual size of an AM is important, but it can be underestimated at least one $\mathrm{cm}$ by modalities such as $C T$ and MRI scans. We know that the risk of malignancy in an AM increases with the size [6]. National Institute for Health and American Association for Clinical Endocrinologists reported the risk of ACC at 25\% for AMs with the diameter more than $6 \mathrm{~cm}, 5 \%$ for AMs for between 4-6 $\mathrm{cm}$, and $2 \%$ for smaller than $4 \mathrm{~cm}$ in size [4]. On the other hand, some AMs are in high-density, hormone-inactive but smaller than $4 \mathrm{~cm}$ or in low-density, hormone-inactive and between 4 and $6 \mathrm{~cm}$ without radiological signs of malignancy. ADX was recommend in the case of AMs more than $3 \mathrm{~cm}$ in diameter in young patients, whereas more than $5 \mathrm{~cm}$ in older patients [14]. The rate of malignancy of the AMs with diameters of less than $4 \mathrm{~cm}, 4-6 \mathrm{~cm}$, and more than $6 \mathrm{~cm}$ to be $0 \%$, $2.9 \%$, and $13.6 \%$ [15]. In our study, histopathologically benign lesions are much smaller than malign lesions, the average diameters of ACC were $98.8 \mathrm{~mm}$. In our study one ACC and one lung metastasis lesions are both $14 \mathrm{~mm}$ in size that is very small AMs than expected to be malignant.

One of the AMs was clinically misdiagnosed as an AAC before operation and reported a follicular dendritic cell sarcoma after histopathologic analysis. Follicular dendritic cell sarco$\mathrm{ma}$ is an uncommon tumor and was originally described as a non-lymphomatous primary lymph node malignancy in 1986 [16]. Usually arises in lymph nodes of the cervical, mediastinal, or axillary areas, but rarely in extranodal sites such as small intestine, mesocolon, pancreas, liver, mesentery and the abdominal wall [17]. Retroperitoneal ones have been only sporadically reported. On contrast enhanced CT scan, follicular dendritic cell sarcoma usually appears homogeneous masses but, like ACC, heterogeneity as a result of necrosis or hemorrhage can be seen [18]. Complete surgical resection is the treatment of choice but chemotherapy and radiation therapy modalities have been also used to treat follicular dendritic cell sarcoma.

Adrenal is the fourth frequent site of metastases from malignant cancers. Breast, lung, prostate, colon and renal cancer, and melanoma prefer to metastases to adrenal. In our study, 8 patients out of 13 malignant AMs were metastases. One cancer patient cohort study reported up to $50 \%$ to $75 \%$ of Al was metastases and postmortem series reporting the incidence up $38 \%[19,20]$. The prevalence of metastatic lesions among Al reported up to $2.5 \%$ [4]. Metastases to adrenal glands are more in men and we also found that metastatic lesions dominated in men [21].

Non-squamaous lung carcinomas often metastases to adrenal and we operated 5 such adrenal metastases including two very rare pleomorphic and adenocarcinoma with enteric morphology. Pleomorphic carcinoma is a rare and aggressive pulmonary malignancy and metastases to the brain, liver, adrenal tissue, and bone have been reported. Other rarely seen lung adenocarcinoma with enteric morphology is a special type of primary adenocarcinoma which shares some identical components with colorectal carcinoma. Its metastases to adrenal also well expected. In addition, we have operated intraglandular metastases of two RCC and one colon cancer to adrenal and one of RCC was to contralateral site. While ipsilateral intra-glandular adrenal metastasis of renal cell carcinoma is well known due to its anatomical location, but isolated contralateral adrenal metastasis is extremely rare. In autopsy studies, only up to $2.5 \%$ found to have the contralateral adrenal gland as the sole site of metastasis [22].

Many research reported significant survival improvement and pain palliation with surgical interventions in some metastatic AMs [22]. Multidisciplinary oncologic evaluation and patient's functional status are important before deciding any surgical interventions. In our study, we performed ADX in five from lung, two intraglandular metastases from renal cell and one colon cancers for curative intention after multidisciplinary consultation.

Nowadays, laparoscopic ADX is the preferred surgical technique to resect any AMs. With the recent advances, a robotic approach is also an important option. With the advantages of less blood loss, quicker recovery and hospitalization, the laparoscopic approach has improved surgical results compared to the open ADX [23-25]. Even, laparoscopic ADX was recommended and shown it a feasible, safe and superior treatment option for pheochoromacytoma [26]. However, both laparoscopic and robotic ADX for adrenal malignancies remains uncertain on oncologic outcomes $[27,28]$. Open surgery is recommended when the tumor is large or suspected to be malignant [6]. On the other hands, data from some series have shown that minimal invasive ADX could be performed in some selected metastases $[29,30]$. We generally preferred laparoscopic operations to masses less than $60 \mathrm{~mm}$ and benign but the median size of our AMs resected with laparoscopic ADX was $43.8 \mathrm{~mm}(10-90 \mathrm{~mm})$ and open was $88.33 \mathrm{~mm}$ (14-190 $\mathrm{mm}$ ). In addition, we performed laparoscopic operation in three malignant suspected lesions but only one of them was reported histopathologically as a lung cancer metastasis.

In conclusion, adrenal is a site of many non-functional and also hormone active benign and malignant lesions and metastases. Adrenal masses should be resected if hormone active or malignancy present. Laparoscopic surgery is feasible in benign lesions and also in some of the malignant lesions. Rarely seen lung cancer metastases, contralateral site renal cell carcinoma metastasis and also some rare sarcoma can be encountered when evaluating an adrenal mass.

\section{Conflict of Interest}

We all authors declare that there is no conflict of interest.

\section{Acknowledgments}

The authors received no specific funding for this work. The authors also received no financial support for the research, authorship, and/or publication of this article.

\section{References}

1. Bovio S, Cataldi A, Reimondo G, et al. (2006) Prevalence of adre- 
Citation: Aktekin A, Kına U, Tanrıkulu S, et al. (2020) Demographic and Clinicopthologic Properties of Patients Operated for Adrenal Masses. J Surgical Endocrinol 2(1):30-35

nal incidentaloma in a contemporary computerized tomography series. J Endocrinol Invest 29: 298-302.

2. Fassnacht M, Arlt W, Bancos I, et al. (2016) Management of adrenal incidentalomas: European society of endocrinology clinical practice guideline in collaboration with the European network for the study of adrenal tumors. Eur J Endocrinol 175: G1-G34.

3. Terzolo M, Stigliano A, Chiodini I, et al. (2011) AME position statement on adrenal incidentaloma. Eur J Endocrinol 164: 851870.

4. Zeiger MA, Thompson GB, Duh QY, et al. (2009) American association of clinical endocrinologists and American association of endocrine surgeons medical guidelines for the management of adrenal incidentalomas: Executive summary of recommendations. Endocr Pract 15: 430-433.

5. Lee JM, Kim MK, Ko SH, et al. (2017) Clinical guidelines for the management of adrenal incidentaloma. Endocrinol Metab (Seoul) 32: 200-218.

6. Chyrek EC, Parulska ES, Olejarz M, et al. (2019) Malignancy risk and hormonal activity of adrenal incidentalomas in a large cohort of patients from a single tertiary reference center. Int J Environ Res Public Health 16: 1872.

7. Di Dalmazi G, Vicennati V, Garelli S, et al. (2014) Cardiovascular events and mortality in patients with adrenal incidentalomas that are either non-secreting or associated with intermediate phenotype or subclinical Cushing's syndrome: A 15-year retrospective study. Lancet Diabetes Endocrinol 2: 396-405.

8. Kim BY, Chun A, Kim KJ, et al. (2014) Clinical characteristics and metabolic features of patients with adrenal incidentalomas with or without subclinical cushing's syndrome. Endocrinol Metab (Seoul) 29: 457-463.

9. Mosso L, Carvajal C, Gonzalez A, et al. (2003) Primary aldosteronism and hypertensive disease. Hypertension 42: 161-165.

10. Miller BS, Else T, AACE Adrenal Scientific Committee (2017) Personalized care of patients with adrenocortical carcinoma: A comprehensive approach. Endocr Pract 23: 705-715.

11. Young WF Jr (2000) Management approaches to adrenal incidentalomas. A view from Rochester, Minnesota. Endocrinol Metab Clin North Am 29: 159-185.

12. Icard P, Goudet P, Charpenay C, et al. (2001) Adrenocortical carcinomas: Surgical trends and results of a 253-patient series from the French association of endocrine surgeons study group. World J Surg 25: 891-897.

13. Ye YL, Yuan XX, Chen MK, et al. (2016) Management of adrenal incidentaloma: The role of adrenalectomy may be underestimated. BMC Surgery 16: 41.

14. Sturgeon C, Shen WT, Clark OH, et al. (2006) Risk assessment in 457 adrenal cortical carcinomas: How much does tumor size predict the likelihood of malignancy? J Am Coll Surg 202: 423-430.
15. Vural V, Kılınç EM, Sarıdemir D, et al. (2020) Association between tumor size and malignancy risk in hormonally inactive adrenal incidentalomas. Cureus 12: e6574.

16. Kairouz S, Hashash J, Kabbara W, et al. (2007) Dendritic cell neoplasms: An overview. Am J Hematol 82: 924-928.

17. Low SE, Menasce LP, Manson CM (2007) Follicular dendritic cell sarcoma: A rare tumor presenting as an abdominal mass. Int J Surg Pathol 15: 315-317.

18. Li L, Shi Y-H, Guo ZJ, et al. (2010) Clinicopathological features and prognosis assessment of extranodal follicular dendritic cell sarcoma. WJG 16: 2504-2519.

19. Lam K, Lo C (2002) Metastatic tumours of the adrenal glands: A 30-year experience in a teaching hospital. Clin Endocrinol (Oxf) 56: 95-101.

20. Abrams H, Spiro R, Goldstein N (1950) Metastases in carcinoma; analysis of 1000 autopsied cases. Cancer 3: 74-85.

21. Arnaldi G, Boscaro M (2012) Adrenal incidentaloma. Best Pract Res Clin Endocrinol Metab 26: 405-419.

22. Collinson F, Lam T, Bruijn W, et al. (2008) Long-term survival and occasional regression of distal melanoma metastasis after adrenal metastasectomy. Ann Surg Oncol 15: 1741-1749.

23. Chuan-Yu S, Yat-faat H, Wei-hong D, et al. (2014) Laparoscopic adrenalectomy for adrenal tumors. Int J Endocrinol 2014: 241854.

24. Conzo G, Gambardella C, Candela G, et al. (2018) Single center experience with laparoscopic adrenalectomy on a large clinical series. BMC Surg 18: 2.

25. Conzo G, Pasquali D, Gambardella C, et al. (2014) Long-term outcomes of laparoscopic adrenalectomy for Cushing disease. Int J Surg 12: S107-S111.

26. Li J, Wang Y, Chang X, et al. (2020) Laparoscopic adrenalectomy (LA) vs open adrenalectomy (OA) for pheochromocytoma (PHEO): A systematic review and meta-analysis. European Journal of Surgical Oncol 46: 991-998.

27. Cooper AB, Habra MA, Grubbs EG, et al. (2013) Does laparoscopic adrenalectomy jeopardize oncologic outcomes for patients with adrenocortical carcinoma? Surg Endosc 27: 4026-4032.

28. Leboulleux S, Deandreis D, Al Ghuzlan A, et al. (2010) Adrenocortical carcinoma: Is the surgical approach a risk factor of peritoneal carcinomatosis? Eur J Endocrinol 162: 1147-1153.

29. Vazquez BJ, Richards ML, Lohse CM, et al. (2012) Adrenalectomy improves outcomes of selected patients with metastatic carcinoma. World J Surg 36: 1400-1405.

30. Moreno P, de la Quintana Basarrate A, Musholt TJ, et al. (2020) Laparoscopy versus open adrenalectomy in patients with solid tumor metastases: results of a multicenter European study. Gland Surg 9: S159-S165. 